\title{
Processing of gong oil (Pachymerus Nucleorum) to obtain biodiesel by methyl route
}

\section{Processamento de óleo de gongo (Pachymerus Nucleorum) para obtenção de biodiesel por rota metílica}

\author{
José Sebastião Cidreira Vieira ${ }^{1 *}$; Wilame Silva Castro ${ }^{1}$; Hugo da Costa Reis ${ }^{1}$; Makson Rangel \\ de Melo Rodrigues ${ }^{1}$; Taciano Pessoa ${ }^{1}$; Milton de Sousa Falcão ${ }^{1}$; Davina Camelo Chaves²;
}

Efraim Costa Pereira ${ }^{3}$

\begin{abstract}
RESUMO
Dentre as espécies com potencial para a obtenção de biodiesel no Brasil, destacam-se o gongo (Pachymerus nucleorum), um besouro, que vive dentro de frutos de buriti (Mauritia flexuosa), tucum (Bactris setosa) e babaçu (Attalea speciosa) até a fase adulta. Este trabalho teve por objetivo extrair o óleo do gongo e adequálo para produção de biodiesel por transesterificação tradicional. A caracterização físico-química do óleo in natura revelou elevado teor de ácidos graxos livres (1,63 e 1,74\% AGL). O óleo de foi submetido ao processo de esterificação por catálise ácida e os resultados indicaram uma redução significativa de AGL $(0,85 \%$ e $0,55 \%)$. Os espectros de FTIR do óleo esterificado e do biodiesel revelaram a presença de ésteres metílicos e baixo teor de umidade. O Brasil é um grande produtor mundial de óleos vegetais. Esta condição o coloca na vanguarda do uso de combustíveis renováveis do planeta, e pode se constituir em uma excelente oportunidade de desenvolvimento científico e tecnológico do país.
\end{abstract}

Palavras-chave: Pachymerus nucleorum; Biodiesel; Sustentabilidade.

\footnotetext{
ABSTRACT

Among the species with potential for obtaining biodiesel in Brazil is the gong (Pachymerus nucleorum), a beetle that lives inside fruits of buriti (Mauritia flexuosa), tucum (Bactris setosa) and babassu (Attalea speciosa) until the adult stage. This work aimed to extract the gong oil and make it suitable for biodiesel production by traditional transesterification. The physical-chemical characterization of the oil in natura revealed a high content of free fatty acids (1.63 and 1.74\% FFA). The oil was submitted to esterification process by acid catalysis and the results indicated a significant reduction of FFA $(0.85 \%$ and $0.55 \%)$. The FTIR spectra of the esterified oil and biodiesel revealed the presence of methyl esters and low moisture content. Brazil is a large world producer of vegetable oils. This condition puts it at the forefront of the use

$1^{*}, 2,3,4,5$ Instituto Federal do Maranhão, Campus Zé Doca

${ }^{6}$ Instituto Federal do Ceará, Campus Acopiara

${ }^{7}$ Universidade Federal do Maranhão, Campus Balsas

1*sebastiaocidreira@ifma.edu.br
} 
of renewable fuels on the planet, and may constitute an excellent opportunity for scientific and technological development of the country.

Keywords: Pachymerus nucleorum; Biodiesel; Sustainability.

\section{INTRODUCTION}

Energy has established itself as an input of fundamental importance for economic growth and for raising the standard of living of modern society. Energy generation is overly dependent on petroleum derivatives. On the other hand, the gases emitted by gasoline, diesel and other derivatives have strongly contributed to environmental degradation, causing climate change, global warming, melting of the polar ice caps, rising sea levels, environmental disasters and destruction of the ozone layer. These events have negatively impacted the economy and public health policies. The limitation of oil reserves and the degradation of the environment are factors responsible for the incessant search for renewable energy sources to redeem and/or eliminate the impacts caused by fossil fuels to the environment (ARANSIOLA et al., 2014; DEY et al., 2021).

Biodiesel has become in the last decades, an alternative fuel capable of meeting the growing demand for energy. The increased demand for energy due to the world population growth has contributed to a possible depletion of fossil energy resources and logically raised the level of atmospheric pollutant emissions, causing environmental degradation (SOUZA et al., 2012). In the current context, most of the energy produced in the world comes from fossil sources such as oil, coal and natural gas, which are directly associated with environmental issues and are responsible for the interest of biodiesel as a renewable fuel, capable of redeeming the emissions of greenhouse gases (POURHSEINI et al., 2021; MURTA et al., 2021).

Biodiesel is a clean-burning fuel, originating from natural and renewable sources such as vegetable oil, saturated edible oil generated from cooking and frying food, animal fat and a shortchain alcohol in the presence of a catalyst. This energy input has properties such as freedom from sulfur and aromatic compounds, high cetane number, average oxygen content, higher flash point, lower emission of hydrocarbon particles, carbon monoxide and dioxide, non-toxic and biodegradable character, which overlap in relation to the properties of petroleum derivatives (POUSA, SANTOS, SUAREZ, 2007; SUAREZ et al., 2007; ALEGRIA, ARRIBA, 2014; CUELLAR et al., 2014). 
The biodiesel production route most used today in Brazil and in the world is called transesterification. In this process, the triacylglycerides (TAG) present in the fatty raw materials, vegetable and animal oils and/or fats interact chemically with a monoalcohol (methanol or ethanol) in the presence of a basic Brönsted type catalyst (proton receptor chemical species) to be converted into a mixture of esters (methyl or ethyl) of fatty acids (biodiesel) and glycerin as a byproduct (MELERO, IGLESIAS, MORALES, 2009; ZUO et al, 2013). Figure 1 below shows the overall reaction process of the traditional transesterification process in the light of chemistry.

Figure 1 - Global reaction of triacylglycerides alcoholysis
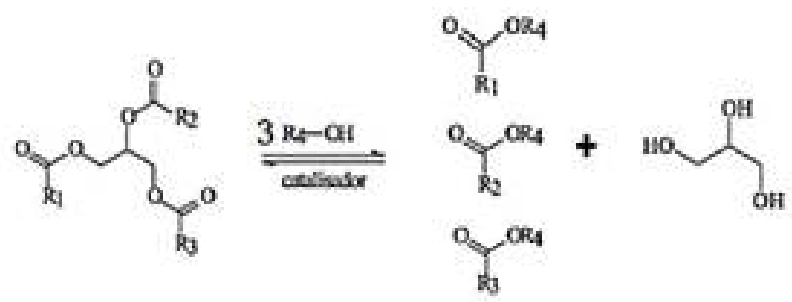

Source: Castro (2019).

Transesterification occurs in three consecutive and reversible steps. To achieve relevant results in the course of traditional transesterification, excess short-chain alcohol is added, since the presence of water in the reaction medium (this occurs very often) even in small amounts (the reactants are hygroscopic). The basic catalysts are very sensitive by means of free fatty acids (FFA) from the fatty feedstock or formed by hydrolysis of the esters. In this system, the FFA react with the alkaline catalyst $(\mathrm{NaOH}$ or $\mathrm{KOH})$ contributing to the formation of fatty acid salts (soaps), which in turn, at the end of the reaction, form emulsions and make it difficult to separate the product (biodiesel) from the by-product (glycerin). The use of Brönsted basic catalysts in the production of biodiesel by homogeneous catalysis requires the use of high quality grease raw materials. The acquisition of these raw materials results in a high cost and account for more than 85\% of biodiesel processing expenses, as it requires the use of anhydrous alcohol and food grade oils and fats (ENCINAR, SANCHEZ, GARCIA, 2011; DRELINKIEWICZ et al., 2014). Due to the basic catalysts, proton receptors (Brönsted), present high catalytic activity and are low cost and little aggressive of the equipment of the transesterification process are the most used in the biodiesel industry. The use of high purity raw materials in biodiesel production processes is one of the main factors that make it difficult for biodiesel to be more competitive in relation to petroleum derived fuels. In view of the 
above, the search for alternative feedstocks capable of reducing the costs of the alkaline transesterification process has led to studies aimed at the use of materials generated from renewable resources to make the production of biodiesel ecologically sustainable and economically viable, which meets the needs of the industrial sector and puts an affordable fuel on the consumer market. Among the raw materials with potential to overcome the limitations of traditional transesterification are oils and fats from oilseed plants, animals and residual raw materials, since they can be acquired at low cost and contribute to the sustainable production of biodiesel. On the other hand, these feedstocks have high acidity index and water content, the main factors that increase the costs of the process and consequently biodiesel becomes less competitive in relation to petroleum diesel. To adapt them to basic homogeneous catalysis technology, it is necessary to previously submit them to the degumming or esterification process by acid homogeneous catalysis to reduce the intrinsic drawbacks of these feedstocks (NATJA-NAN et al., 2015; ALCHRIS et al., 2016).

Due to its territorial extension and the variety of climates and soils, Brazil performs the biodiesel processing in a decentralized way at laboratory scale level, valuing the abundant raw materials in each of its regions. Thus, new alternatives for obtaining biodiesel are constantly being tested. This means that different routes and scales of production, different raw materials and inputs should be studied, whose purpose is to evaluate the quality of biodiesel produced (SOUZA et al., 2012). In this context, an attractive alternative for the production of biodiesel in the Meso Region of Alto Turi, specifically in the municipality of Zé Doca (Maranhão, Brazil), lies in the transesterification of oils extracted from numerous oleaginous plants and animal fats. This locality presents conditions to generate different biofuel production routes. Among the various species with potential for the production of biodiesel, the gong or coconut bug (Pachymerus nucleorum) stands out. When subjected to heating, it decomposes, originating an oil equal to that extracted from the seeds of oilseed plants. It is the larval stage of a coleopteran of the family Bruchidae, a beetle, which lives inside fruits of buriti (Mauritia flexuosa), tucum (Bactris setosa), babaçu (Orbignya speciosa) and carnauba (Copernicia prunifera) until the adult stage. (OLIVEIRA, 2008; FERREIRA, 2010; SOUZA, 2012).

The adult female lays her eggs on the palm seeds at the time of infructescence, when the shell is forming and is less hard. The eggs hatch about 10 days later and the 
larvae penetrate the fruit. In this larval stage, lasting up to 90 days, the coleopteran (beetle) has a white color, black ocelli at one end of the body, along with the mouthpiece and is about $2 \mathrm{~cm}$ long as can be seen in Figure 2 (FERREIRA, 2010).

Figure $2-$ Visual aspecto of the gong

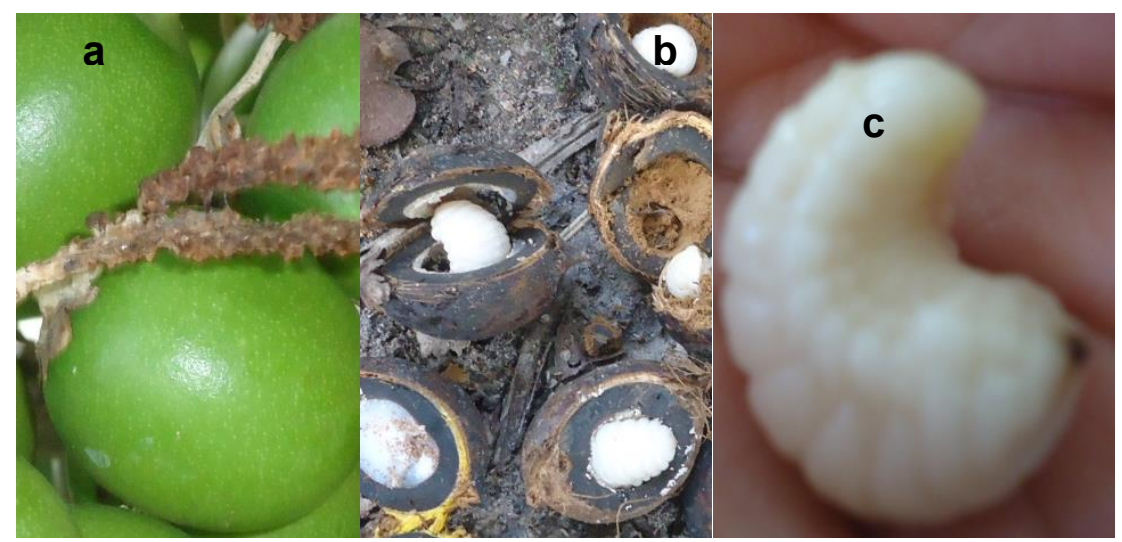

Legenda: a: tucum coconut, b: gong in tucum endocarp and c: gong

Source: Castro (2019).

It is believed that the production of biodiesel from the oil extracted from the gong is an innovative idea and with relevant potential for society. In the literature, so far, no work has been found on this energy input and its use in the production of biodiesel. The production of biodiesel in Brazil, besides being an alternative for energy self-sufficiency, can also generate employment and income opportunities and contribute to the settlement of people in the countryside.

\section{OBTAINING BIODIESEL ON A LABORATORY SCALE}

\subsection{SAMPLE COLLECTION}

As discussed earlier, biodiesel can be obtained from low value-added fat feedstocks, i.e., with high free fatty acid (FFA) content. Such feedstocks are pretreated to suit the alkaline methanol transesterification process.

Initially, in native forest in the municipality of Zé Doca (Maranhão, Brazil), tucum (Bactris setosa) coconuts were collected, containing a small hole in its endocarp, indicative of containing the gong (Pachymerus nucleorum) inside these materials. The endocarp of the selected coconuts was broken and the gongs were removed from its interior. 


\subsection{THERMAL EXTRACTION OF COCONUT OIL}

The larvae of Pachymerus nucleorum are washed thoroughly with clean water in a $1.00 \mathrm{~mm}$ sieve. They are then added to an aluminum tank with a capacity of $2000 \mathrm{~mL}$ and heated to about $120^{\circ} \mathrm{C}$, until they release all the oil contained in them. After cooling, the oil is filtered and stored in polyethylene bottles and made available for physicalchemical characterization.

The extractive performance of gong oil is evaluated as a function of the refined oil mass and the mass of oil used throughout the extraction. The yield was calculated using the following equation.

$$
I N C O M E=\frac{\text { OIL } \operatorname{produced}(g)}{\text { Gongoused }(g)} \cdot 100
$$

\subsection{PHYSICAL-CHEMICAL CHARACTERIZATION OF THE OIL EXTRACTED FROM THE GONG}

The oil extracted from Pachymerus nucleorum larvae was physicochemically characterized in terms of acidity index (A.I.), free fatty acids (FFA), moisture content $(\% \mathrm{H} 2 \mathrm{O})$, density (D) and saponification index (Is) as recommended (MORETO, ALVES, 1986; IAL, 2004; TECBIO, 2008).

The acid value is defined as the number of milligrams of potassium hydroxide ( $\mathrm{mm} \mathrm{KOH} / \mathrm{g}$ of sample) sufficient to neutralize the fatty acids present in a given quantity of oil or fat. This parameter is determined by the neutralization titrimetric method. In a typical assay, approximately $2.0 \mathrm{~g}$ of the sample is weighed into a $250 \mathrm{~mL}$ conical flask and $25 \mathrm{~mL}$ of neutralized alcohol $\left(96^{\circ} \mathrm{GL}\right.$ ethanol + ethyl ether in a 1:2 ratio) and 3 to 5 drops of the phenolphthalein indicator are added. This mixture was titrated with $0.1 \mathrm{Mol}$. L-1 until it turned from colorless to pink. The acidity index was expressed in $\mathrm{mg} \mathrm{KOH} / \mathrm{g}$ of sample and calculated using the equation below:

$$
I A=\frac{V_{\text {spend }} \cdot[\mathrm{NaOH}] \cdot f_{\mathrm{C}} \cdot 56,1}{P_{\text {sample }}}
$$


Where, Vgasto is the volume of $\mathrm{NaOH}$ spent in the titration; $[\mathrm{NaOH}]$ is the molar concentration of $\mathrm{NaOH}$; fc is the correction factor of the $\mathrm{NaOH}$ solution; 56.1 milliequivalent gram of $\mathrm{KOH}$ and Pamsample is the weight of the sample.

The content of free fatty acids (FFA) contained in the samples is determined analogously to the acid value. The percentage of free fatty acids in terms of oleic acid (O.A.) was calculated according to the following equation.

$$
A G L=\frac{V_{\text {spend }} \cdot[\mathrm{NaOH}] \cdot f_{c} \cdot 28,2}{P_{\text {sample }}}
$$

Where, 28.2 corresponds to the milliequivalent gram of oleic acid.

The determination of the water content consists of the difference between the mass of the sample considered wet (Aúmida) and the mass of the dry sample (Aseca) after being submitted to drying in an oven for a period of 3 hours at $110 \pm 5^{\circ} \mathrm{C}$. The percentage of water contained in the samples was determined by the following equation.

$$
\% \mathrm{H}_{2} \mathrm{O}=\frac{\operatorname{Peso}\left(A_{\text {wet }}-A_{\text {dry }}\right)}{\operatorname{Peso}\left(A_{\text {wet }}\right)} \times 100
$$

The saponification index (Is) is defined as the number of milligrams of potassium hydroxide required to neutralize the fatty acids, resulting from the hydrolysis of one gram of the sample. The saponification index is determined by the Koesttstafer method, and consisted of heating a mixture containing $2.0 \mathrm{~g}$ of the sample and $25 \mathrm{~mL}$ of $4 \%$ alcoholic $\mathrm{KOH}$ solution, with a reflux cooler, for 30 minutes at a mild temperature (approximately $50{ }^{\circ} \mathrm{C}$ ), followed by titration with hydrochloric acid at $0.5 \mathrm{Mol}$. L-1. Analogously, a blank sample is carried out. The saponification index was determined by the following equation.

$$
I_{S}=\frac{\left(V_{\text {white }}-V_{\text {sample }}\right) \times f_{C} \times 28}{\text { Wheight }_{\text {sample }}}=m g K O H / g_{\text {sample }}
$$

Where, Vsample is the volume of $\mathrm{HCl}$ spent in the titration of the treated sample; Vblank is the volume of $\mathrm{HCl}$ spent in the titration of the blank sample; fc is the correction factor and SampleWeight is the weight of the sample used during the analysis. 
Density is the mass per unit volume at a specified temperature. Parameter determination was performed by the pycnometry method. In a typical analysis, a $5 \mathrm{~mL}$ capacity pycnometer was weighed dry $(\mathrm{m} 1)$. Vegetable oil was then added until it reached its maximum capacity. The system was weighed (m2) again and by mass difference (m2$\mathrm{m} 1$ ) the mass of the oil and its density (D) were determined using the following equation:

$$
D=\frac{\text { mass }_{\text {oil }}}{\text { Volume }_{\text {pycnometer }}} \quad \text { Eq. }(\mathrm{F})
$$

\subsection{HETEROGENEOUS ACID ESTEREFICATION FROM GONG OIL}

The gong oil samples containing high free fatty acid (FFA) content are previously treated by the homogeneous acid esterification method, in order to reduce the acidity content and make it suitable for homogeneous alkaline transesterification. In this step the homogeneous acid catalyst, sulfuric acid (H2SO4) is used.

The homogeneous acid esterification reactions are carried out in a round bottom flask of $500 \mathrm{~mL}$ capacity, coupled to a reflux system kept under rigorous stirring at $70{ }^{\circ} \mathrm{C}$ for 3 hours.

In a typical experiment, $0.018 \mathrm{~mol}$ of gong oil is added $0.142 \mathrm{~mol}$ of methanol and $0.4 \%$ catalyst relative to the base mass of the oil, with a molar ratio of 1:8 (one to eight) between the oil and methanol. The system is kept in rigorous stirring throughout the process. The reaction time consisted of 240 minutes and temperature around $90{ }^{\circ} \mathrm{C}$. The product is recovered using the centrifugation technique, rotating at $2500 \mathrm{rpm}$, for 15 minutes. The oily part is subjected to heating at $100^{\circ} \mathrm{C}$, to eliminate water and methanol residues and destined later for physicalchemical characterization, to measure the efficiency of the esterification process and also for biodiesel production by conventional alkaline transesterification methylation route.

\subsection{BASIC TRASNESTERIFICATION OF ESTERIFIED GONG OIL}

The esterified gong oil containing reduced free fatty acid content is subjected to the traditional basic transesterification process to obtain biodiesel.

The biodiesel production is carried out in a flat-bottomed flask containing three mouths and $250 \mathrm{~mL}$ capacity, coupled to a reflux system. 
In a typical experiment, $5.0 \mathrm{~g}(0.018 \mathrm{~mol})$ of the starting vegetable oil is added to $4.6 \mathrm{~g}$ of methanol $(0.144 \mathrm{~mol})$ and $0.05 \mathrm{~g}$ of alkaline catalyst, $\mathrm{NaOH},(1 \%$ relative to the base mass of the oil), with a molar ratio of 1:8 (one to eight) between the oil and methanol. The system is kept under strict magnetic stirring throughout the process. The reaction time consisted of 120 minutes and temperature of $90{ }^{\circ} \mathrm{C}$. The reaction mixture is added into a settling funnel for phase separation. The lower, glycerinous phase (by-product) was discarded and the upper phase (methyl ester mixture) was washed with acidulated sulfuric acid water (H2SO4 at $0.01 \mathrm{Mol}$. L-1) and subsequently with heated water until the final product was clear. Figure 3 shows the traditional alkaline transesterification process of obtaining biodiesel from esterified gong oil.

Figure 3 - Basic homogeneous transesterification process of gong oil

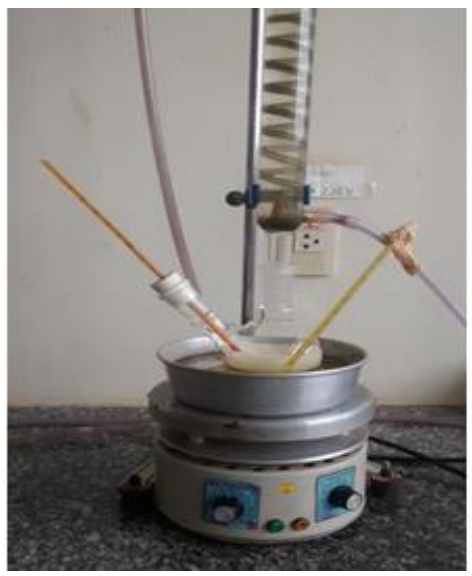

Source: Castro (2019).

\subsection{CHARACTERIZATION OF GONGO BIODIESEL}

Different electroanalytical techniques are currently used to quantify and qualify biodiesel aiming the knowledge of the physical-chemical profile of this energy input and also to adapt it to the specifications required by the National Agency of Petroleum, Natural Gas and Biofuel (ANP), the Brazilian agency responsible for the quality control of petroleum products and biofuels. In this specific case, biodiesel was characterized in terms of spectroscopy in the infrared region (IR) and gas chromatography (GC).

\subsubsection{Fourier transform infrared spectrocospy}

Fourier transform infrared spectroscopy (FTIR) is a widely used technique in qualitative analysis, synthesis, and biochemical transformations. FTIR measures the 
vibrational transition when a material absorbs energy in the infrared (IR) region. Different functional groups and their bond types exhibit infrared absorption frequencies and intensities. This electroanalytical technique is a highly relevant tool for identification and structural elucidation of a chemical substance, in addition to enabling the control and monitoring of reactions (RAMPAZZO, 2015).

The absorption spectra in the infrared region with Fourier transform (FTIR) for the esterified gong oil and biodiesel were recorded in the range of 400-4000 cm-1, using a $\mathrm{KBr}$ tablet. The tests were performed at the Institute of Chemistry, UFRJ, in a PerkinElmer spectrophotometer, model spectrum 100 with spectral resolution of $4 \mathrm{~cm}-1$.

\subsubsection{Gas chromatography with flame ionization detector}

The chromatography technique with flame ionization detector (GC-FID) is used for the determination of the total content of fatty acid methyl or ethyl esters (FAME) from the transesterification reaction of vegetable oils and/or animal fats. The ANP specifications contained in Resolution No. 45 of August 2014 (ANP 45/2014) for analysis of the content of esters present in biodiesel were constituted based on the EN 14103 and ANBT 15342 standards. The technique of gas chromatography with flame ionization detector (GC-FID) for determination of the total ester content requires analytical standards of each FAME to confirm the results (RAMPAZZO, 2015).

Compositional analysis of the constituent methyl esters of biodiesel produced from esterified gong oil was performed using a gas chromatograph 7890A CG series from Agilent Technologies coupled with a flame ionization detector (GC-FID). This equipment used a CPWAX 52CB capillary column $30 \mathrm{~m}$ long, internal diameter $0.25 \mathrm{~mm}$, film thickness $0.25 \mu \mathrm{m}$, under the following conditions: injection volume $=0.5 \mu \mathrm{L}$, oven at $175^{\circ} \mathrm{C}$, injector temperature at $250^{\circ} \mathrm{C}$, detector temperature $=390^{\circ} \mathrm{C}$, hydrogen pressure $=200 \mathrm{kPa}$, flow rate of $2 \mathrm{~mL}$ min- 1 and analysis time of 20 minutes. After obtaining the chromatogram the composition was calculated from the area of each of the respective fatty acid esters. The characterization of the biodiesel fat profile of gong by GC-FID was performed at the School of Chemistry, Federal University of Rio de Janeiro.

\section{RESULTS AND DISCUSSION}

3.1 THERMAL EXTRACTION OF GONG OIL 
The extracted gong oil presented a physical aspect, with medium viscosity, straw yellow coloration, clear and free of impurities as shown in Figure 3.

Figure 6 - Physical aspect of gong oil in natura

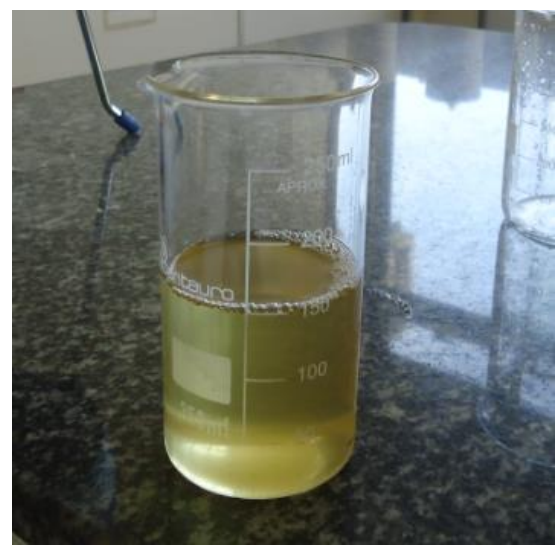

Source: Castro (2019).

In the course of this work, three thermal extractions of the gong oil collected from the tucum coconut (Bactris setosa) were performed. A gravimetric yield in the range of 29 to $38 \%$ was obtained. The following equation shows the gravimetric yield of the second extraction. A total of $599 \mathrm{~g}$ of gong was used and $208.17 \mathrm{~g}$ of oil was obtained.

$$
\text { Incomeect }=\frac{208,17}{599} \times 100=34,75 \%
$$

It is believed that the production of biodiesel from the oil extracted from the gong is an innovative idea. In the literature to date no work has been found on this energy input. Comparing the gravimetric yield of some oilseed plants, such as: corn kernels with $4 \%$, cottonseed with $15 \%$, linseed with $34 \%$, and soybeans with $18 \%$. It must be agreed that the yield of thermal extraction of gong oil is of excellent quality.

\subsection{PHYSICOCHEMICAL PROFILE OF GONG OIL}

Table 1 shows the physicochemical profile revealed for the oil extracted from the gongo in its raw or in natura form. The gongo oil was divided into two samples in order 
to perform its physicochemical characterization. In turn, each sample was divided into three aliquots, the analyses were performed in triplicates totaling 30 assays.

Table 1 - Physical-chemical characterization of gong oil in natura

\begin{tabular}{c|c|c|c|c|c}
\hline \multirow{3}{*}{ Samples } & \multicolumn{5}{|c}{ Quality Control Parameters } \\
\cline { 2 - 6 } & $\mathrm{H}_{2} \mathrm{O}(\%)$ & $\begin{array}{c}\mathrm{IA}(\mathrm{mg} \\
\mathrm{KOH} / \mathrm{g})\end{array}$ & AGL $\%$ A.O $)$ & $\begin{array}{c}\mathrm{I}_{\mathrm{s}}(\mathrm{mg} \\
\mathrm{KOH} / \mathrm{g})\end{array}$ & $\mathrm{D}\left(\mathrm{Kg} / \mathrm{m}^{3}\right)$ \\
\hline AM1 & $\begin{array}{c}0,17 \\
( \pm 0,05)\end{array}$ & $\begin{array}{c}3,26 \\
( \pm 0,41)\end{array}$ & $\begin{array}{c}1,63 \\
( \pm 0,20)\end{array}$ & $\begin{array}{c}103 \\
( \pm 2,16)\end{array}$ & $\begin{array}{c}( \pm 0,00) \\
\end{array}$ \\
\hline AM2 & 0,19 & 3,41 & 1,74 & 204 & 887 \\
& $( \pm 0,00)$ & $( \pm 0,00)$ & $( \pm 0,00)$ & $( \pm 0,00)$ & $( \pm 0,00)$ \\
\hline
\end{tabular}

Source: Castro, (2019).

Acid value and moisture content are the main parameters affecting the sustainable production of biodiesel by the homogeneous alkaline transesterification route. A free fatty acid (FFA) content higher than $0.5 \%$ and a moisture content higher than $0.25 \%$ limit biodiesel production by basic homogeneous catalysis.

The acidity index is a quality parameter that indicates the amount of free fatty acids originating from the hydrolysis of glycerides. A high FFA content is indicative that the oil is undergoing breakdown in the glycerol chains, releasing its main constituents. According to Vieira et al. (2017), the acidity of oils tends to increase with prolonged storage due to the oxidation of free fatty acids, which can compromise their aroma, color, and flavor due to their rancidity process. In this sense, the high acidity values found in Table 1 may be related to the storage time of the samples (6 months) and also to the rudimentary way in which the oil was extracted.

In this work we obtained AI:3.26 mg KOH/g $( \pm 0.41)$ and FFA:1.63\% $( \pm 0.20)$ for sample 1 and AI:3.41 ( \pm 0.00$)$ and FFA: $1.74( \pm 0.00)$ for sample 2. Barbosa et al. (2009), obtained the following results for tucum oil extracted by mechanical pressing IA: 37.5 $\mathrm{mg} \mathrm{KOH} / \mathrm{g}( \pm 0.40)$ and FFA:18.86\% $( \pm 0.26)$ it is noted when comparing the results that in both cases the acidity of the oil extracted from the gong contained in the tucum coconut or properly from the tucum almonds present a high acidity index indicating that the gong oil was not appropriate for biodiesel production, requiring a treatment to adapt it to the biofuel production process. 
Another parameter that influences the biodiesel production is water. This substance deactivates the catalyst forming soap, hinders the separation of product phase (biodiesel) and byproduct (glycerin), besides generating effluents that contaminate the environment. Table $\mathrm{x}$ shows that the average water content was $0.17 \%( \pm 0.05)$ and 0.19 $( \pm 0.00)$ for samples 1 and 2, respectively. Divergent values were found by Freitas and Silva Jr (2017) when studying the moisture content for tucum oil obtaining H2O: 4.4\% ( \pm 0.53). On the other hand, Costa et al. (2017), obtained a moisture content of $0.13 \%$ ( \pm 0.00) for tucum extracted oil. Regarding the moisture content, it can be inferred that the gong oil in natura was within the specification for biodiesel production.

The saponification index (Is) is a property that has a strong influence on the quality of an oil. The saponification reaction can indicate the degree of deterioration and stability of an oil. The gong oil revealed Is:103 mg KOH/g $( \pm 2.16)$ for sample 1 and for sample 2, Is:204 ( \pm 0.00$)$. According to the British standard an oil that is considered first quality should have a saponification index in the range of 177 to $187 \mathrm{mg} \mathrm{KOH} / \mathrm{g}$ of the sample. The higher the saponification index, the greater is its application for food purposes (VIEIRA, 2017). In the view of the English standard, the Is of sample 1 is not first quality. The Is of sample 2, on the other hand, according to Barbosa et al. (2009), is ideal for human consumption and coincidentally this input is widely used for this among the countryside populations. The difference in Is between the analyzed samples may be related to regional climatic conditions, since sample 1 was collected in the dry season (summer) and sample 2 was collected in the rainy season. The rainy season contributes greatly to the rancidity of the oil in natura (crude) because with the increase in moisture content there is hydrolysis of the oil, release of fatty acids and decomposition by the action of microorganisms.

Density is a physicochemical parameter of high relevance in the quality of biodiesel. This parameter is directly related to the chemical composition of the oil used for biodiesel production. The stronger the intermolecular interactions existing in the raw materials the higher the density will be. These interactions increase with the number of carbons in the chain (single bonds) and decrease the greater the number of unsaturated bonds (double bonds) contained in the oil composition. The analysis of the chemical composition of the gong oil performed by gas chromatography (GC) revealed as the majority acid, the C12:0 (lauric acid). In Table 1 the mean density value for gongo oil was $915 \mathrm{Kg} / \mathrm{m} 3( \pm 0.00)$ and $887 \mathrm{Kg} / \mathrm{m} 3$ for samples 1 and 2 respectively. On the other 
hand, Barbosa et al (2009) found similar density (D:889 kg/m3 \pm 0.00 ), for the oil extracted from tucum by the physical method. When an oil suffers the influence of temperature there is a reduction in its density, in biodiesel the density is linked to the cetane number, which is an indicative property in the ignition delay time of diesel cycle engines and the calorific value, directly affecting the engine performance (VIEIRA, 2017). Fuel injection systems, thus, suffer changes in fuel density and influence engine power, in view of the addition of different mass to be injected. In addition, fuel density and viscosity affect injection pressure, fuel atomization, and engine performance.

\subsection{ESTEREFICATION OF GONGO OIL WITH HIGH ACIDITY}

\subsubsection{Homogeneous acid esterification of gongo oil}

Table 2 presents the results of the physicochemical characterization revealed for the esterified gong oil. Regarding the water content, when compared with Table 1 (characterization of the oil in natura), it is observed that there was a significant increase (from 0.17 to 0.8 ) in the moisture content of sample 1 and for sample 2 there was a decrease, around $26 \%$ of moisture (from 0.19 to 0.14 ). The increase in water content in sample 1 may have occurred due to the inefficiency of the dehumidification stage, since during dehumidification water is formed as a byproduct. On the other hand, it is observed that sample 2 met the specification for biodiesel production since it revealed $0.14 \%$.

Tabela 2 - Physical-chemical characterization of esterified gong oil

\begin{tabular}{c|c|c|c|c|c}
\hline \multirow{2}{*}{ Samples } & \multicolumn{5}{|c}{ Quality Control Parameters } \\
\cline { 2 - 6 } & $\mathrm{H}_{2} \mathrm{O}(\%)$ & $\begin{array}{c}\mathrm{IA}(\mathrm{mg} \\
\mathrm{KOH} / \mathrm{g})\end{array}$ & AGL (\%A.O) & $\begin{array}{c}\mathrm{I}_{\mathrm{s}}(\mathrm{mg} \\
\mathrm{KOH} / \mathrm{g})\end{array}$ & $\mathrm{D}\left(\mathrm{Kg} / \mathrm{m}^{3}\right)$ \\
\hline AM1 & 0,8 & 1,5 & 0,85 & 108 & 908 \\
& $( \pm 0,14)$ & $( \pm 0,00)$ & $( \pm 0,07)$ & $( \pm 0,00)$ & $( \pm 0,00)$ \\
\hline AM2 & 0,14 & 1,09 & 0,55 & 103 & 905 \\
& $( \pm 0,08)$ & $( \pm 0,00)$ & $( \pm 0,00)$ & $( \pm 0,00)$ & $( \pm 0,00)$ \\
\hline
\end{tabular}

Source: Castro, (2019).

The acidity index for both sample 1 and sample 2 showed significant reduction in the range of $46 \%$ (from 3.26 to $1.5 \mathrm{mg} \mathrm{KOH} / \mathrm{g}$ ) and $32 \%$ (from 4.41 to $1.09 \mathrm{mg} \mathrm{KOH} / \mathrm{g}$ ) 
respectively. However, these values are above the specification of RDC270 ANVISAMS, whose optimal limit is $0.6 \mathrm{mg} \mathrm{KOH} / \mathrm{g}$ of the sample. Oil treatment by homogeneous acid esterification significantly improved the quality of gong oil for biodiesel production. The FFA content also significantly reduced around 52\% for sample1 (from 1.63 to $0.35 \%$ ) and $32 \%$ for sample $2(1.74$ to $0.55 \%)$. Although the reduction is significant the treatment of the crude oil did not reach the desired specification on the order of $0.5 \%$ in sample 1 , however, in the light of statistics this is a small difference that does not prevent the esterified gong oil from being used in the manufacture of biodiesel.

As for the saponification index (Is), it was observed that there was some stabilization of the said quality control parameter in the range of $103-108 \mathrm{mg} \mathrm{KOH} / \mathrm{g}$ of the sample indicating that according to English quality standards gong oil is not considered first quality.

Regarding the density, it was observed that there was a stable density in the range of $905-908 \mathrm{~km} / \mathrm{m} 3$ as the majority acid in gong oil is C12:0 containing greater intermolecular interaction due to its simple bonds in the carbon chain the density becomes high and tends to reduce when the raw material is subjected to treatment involving high temperature, as occurred with the gong oil in the course of the acid homogeneous esterification process.

The results obtained after the esterification of the gong oil as shown in Table 2 led us to infer that the esterification treatment of this oil was efficient because it significantly reduced the FFA content, but not effective enough to reach the desired level (0.5\% FFA). Figure 3 illustrates the physical aspect of Pachymerus nucleorum and its oils.

Figure 3 - Physical aspect of gong and its crude and esterified oils

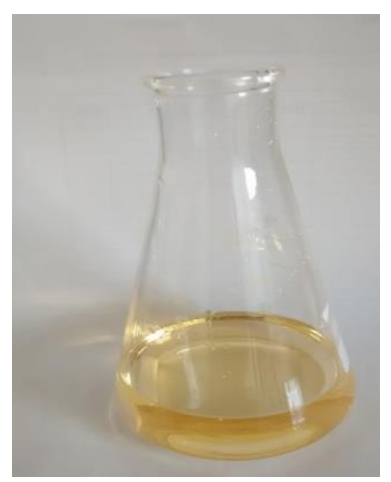

Source: Castro, (2019). 


\subsubsection{Homogeneous transesterification of esterified oil}

The production of biodiesel from fresh gong oil was carried out in two steps: homogeneous acid esterification and homogeneous basic transesterification, using 0.018 mol of oil and $0.142 \mathrm{~mol}$ of transesterification agent (methanol), $1 \%$ alkaline catalyst $(0.05 \mathrm{~g} \mathrm{NaOH})$, in relation to the mass of oil molar ratio between oil and methanol in the order of 1:8 (one to eight), reaction temperature of $90 \mathrm{oC}$ and residence time of 120 minutes.

When the feedstock for biodiesel production contains a high content of free fatty acid, the yield through alkaline homogeneous transesterification method is low with soap formation and deactivation of the catalyst. A viable alternative to adapt this oil to the biodiesel process is its treatment through homogeneous acid esterification aiming to reduce its free fatty acids. Figure 4 shows the visual aspect from the extraction of gong oil to the biodiesel obtained on a laboratory scale from this esterified oil.

Figure 4 - Products obtained from the biodiesel processing steps.

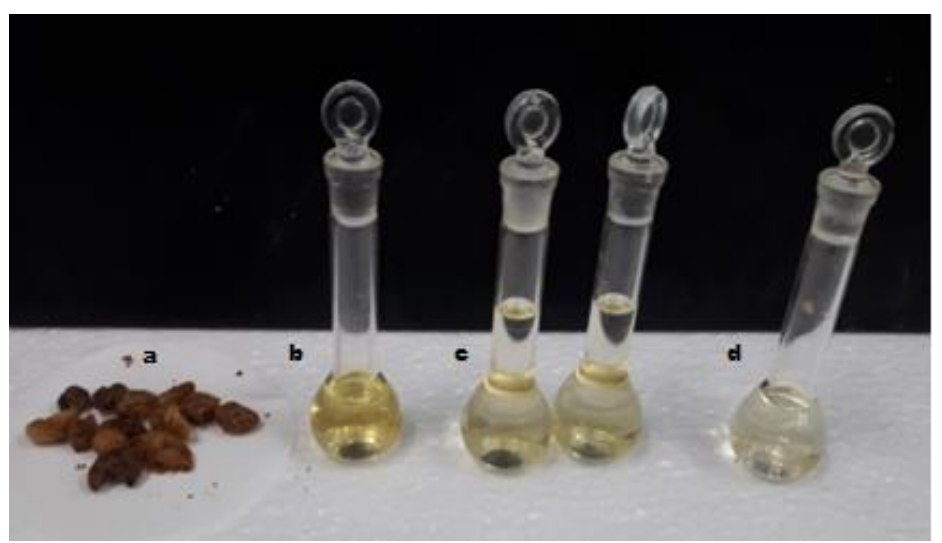

Caption:

a: gongo sludge; b: gongo oil in natura; c: esterified gongo oil and d: gongo biodiesel.

Source: Castro, (2019).

\subsection{CHARACTERIZATION OF GONGO OIL AND BIODIESEL}

\subsubsection{Fourier transform infrared spectroscopy}

The elucidation of the chemical behavior of the products of the homogeneous acid esterification and homogeneous alkaline transesterification reactions of gong oil was investigated using Fourier transform infrared absorption spectroscopy (FTIR). 
The IR spectra of the esterified gong oil (Figure 5 a) and biodiesel (Figure $5 \mathrm{~b}$ ) samples are shown in Figure 5. They showed similar band positions, intensity and wave number. Albuquerque (2006), Silva (2011) and Rampazzo (2015), characterized vegetable oils and biodiesels produced from different vegetable oils and obtained FTIR results similar to the results revealed in this work

Figure 5 - FTIR spectrum of gong oil and biodiesel
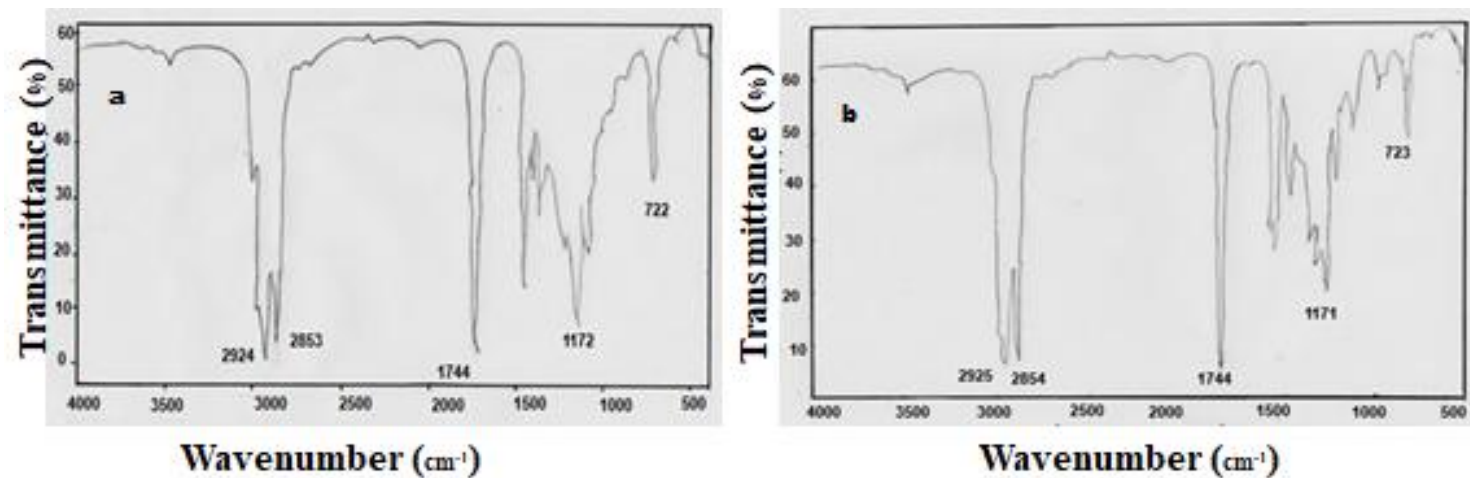

Wavenumber $\left(\mathrm{cm}^{-1}\right)$

In the region of the functional groups that comprises the range $4000-1650 \mathrm{~cm}-1$ few bands were observed. There, three sets of well-defined bands were revealed, two bands in the range 2853-2925 cm-1 referring to the $\mathrm{CH} 2$ stretching of alkanes and one at $1744 \mathrm{~cm}-1$ indicative of the $\mathrm{C}=\mathrm{O}$ (carbonyl) stretching that characterizes the double bond region.

The region between 1650 and $500 \mathrm{~cm}-1$ is called the fingerprint region. In this region more bands were found in relation to the region of the functional groups, however, the bands obtained between 1171-1172 cm-1 allusive to the vibrations of the $\mathrm{C}-\mathrm{O}$ bond, indicative of the stretching of the ester grouping, stand out. Between 722 and $723 \mathrm{~cm}-1$ bands referring to asymmetric $\mathrm{CH}$ deformation, characteristic of long hydrocarbon chains, were revealed. Another relevant factor observed in Figures $5 \mathrm{a}$ and $5 \mathrm{~b}$ was the absence of absorption of broad bands in the region between 2500 and $3300 \mathrm{~cm}-1$, showing that the gongo oil and biodiesel had low moisture content. This fact was confirmed in the course of the immediate chemical analyses shown in Table 2.

\subsubsection{Fat profile of biodiesel obtained by GC-FID}

In Brazil, the National Agency of Petroleum, Natural Gas and Fuel (ANP) is the body responsible for overseeing the quality parameters of biodiesel through Resolution 
No. 45, dated August 13, 2014. It regulates the characteristics of biofuels. The quality parameters are used to determine whether a given product is fit for consumption and not harmful to the population and the environment.

The ideal biodiesel for Resolution 045/2014-ANP should contain in its chemical constitution $100 \%$ of fatty acid methyl esters (FAME), however, in view of the low conversion of monoacylglycerols (MAG), diacylglycerols (DAG) and triacylglycerols (TAG) and competition between the secondary reactions throughout the transesterification process it becomes difficult to separate the esters formed and the reaction impurities. Consequently, at the end of the transesterification reaction, a mixture containing biodiesel and impurities is formed. Hence the importance of characterization of biodiesel and the feedstock that gave rise to it.

Among the specific quality parameters for biodiesel determined by the ANP is the ester content. The ANP has established an ester content of at least 96.5\%. A low ester content directly influences the physical-chemical properties of biodiesel. Therefore, to obtain a high quality biofuel, the transesterification reaction must be complete and the purification process after the reaction must be effective. Thus, the content of remaining contaminants (FFA, methanol traces, water, etc.) should be low, so that the ester content meets the ANP specifications.

The methyl biodiesel produced from the esterified gong oil was characterized by gas chromatography with flame ionization detector (GC-FID) technique for ester conversion. The chromatographic profile in terms of fatty acid methyl esters (FAME) of the biodiesel is presented in Figure 6.

Figure 6 - Chromatographic profile of methyl esters contained in gong biodiesel.

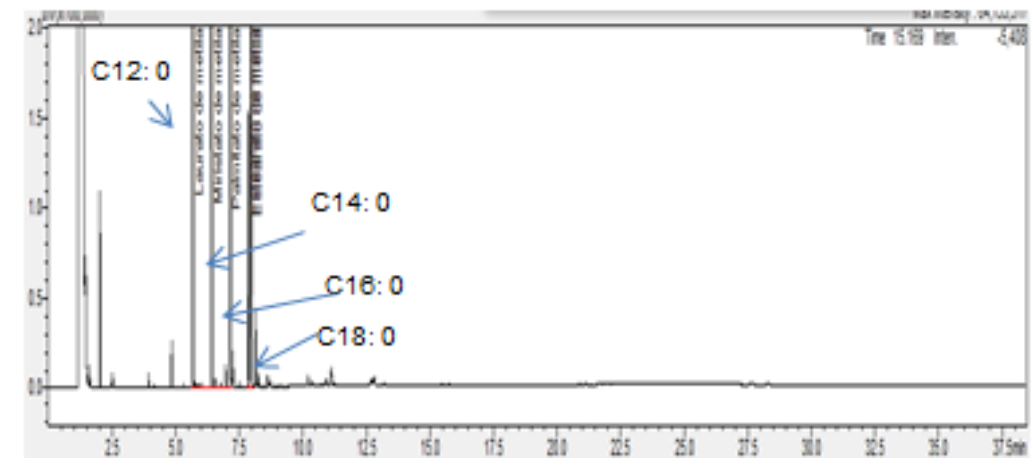

Source: The author himself

The FAME centesimal composition of the biodiesel is shown in Table 3. Therein it was observed that the majority constituent was dodecanoic acid methyl ester (methyl laurate, C 12:0) with 36.85\%; followed by octadecanoic acid methyl ester (methyl 
stearate, C18:0) with $25.47 \%$, tetradecanoic acid methyl ester (methyl myristate, C14:0) with $23.37 \%$ and hexadocanoic acid methyl ester ( methyl palmitate, C16:0) with $14.31 \%$.

Tabela 3 - Composition of fatty acid methyl esters from gong biodiesel

\begin{tabular}{|c|c|c|}
\hline \multicolumn{2}{|c|}{ Ésteres metílicos de ácidos graxos (FAME) } & \multirow{2}{*}{$\begin{array}{l}\text { Quantidade } \\
(\%)\end{array}$} \\
\hline Símbolo & Nome & \\
\hline C 8:0 & Methyl Caprylate & $\mathrm{Nd}$ \\
\hline C $10: 0$ & Methyl Caprolate & $\mathrm{Nd}$ \\
\hline C $12: 0$ & Methyl Laurate & 36,85 \\
\hline C $14: 0$ & Methyl Myristate & 23,37 \\
\hline C $16: 0$ & Methyl Palmitate & 14,31 \\
\hline C $18: 0$ & Methyl stearate & 25,47 \\
\hline C $18: 1$ & Methyl Oleate & $\mathrm{Nd}$ \\
\hline C $18: 2$ & Methyl Linoleate & $\mathrm{Nd}$ \\
\hline \multicolumn{2}{|r|}{ Total percentage } & 100 \\
\hline
\end{tabular}

The technique of gas chromatography with flame ionization detector (GC-FID) is suggested by standards EN 14103 and NBR 15764 for determining the content of fatty acid methyl esters (FAME) from the transesterification reaction of vegetable oils and, to confirm the results are necessary to use analytical standards for each FAME.

According to the ANP (2014), the determination of the ester content can be done following the EN 14103 methodology. The ester content based on this standard is performed by internal standardization with methyl heptadecanoate $(\mathrm{C} 17: 0)$ and only considers the esters of chain from C14:0 to C24:1 in the calculation of the ester content. Since in the characterization of biodiesel produced from gong oil it was revealed that the majority fatty acid methyl ester was C12:0 (methyl laurate), the EN 14103 technique did not allow determining the conversion of esterified gong oil into biodiesel (methyl esters). Due to financial and technical difficulties that permeate our institution it was not possible to use other means to do the conversion. On the other hand, comparing the FTIR results for the esterified gongo oil and biodiesel with the results revealed for the fat profile of gongo biodiesel through the GC-FID technique is notable the presence of bands in the infrared absorption region allusive to the axial deformation of carbonyl $(\mathrm{C}=\mathrm{O})$ indicating the presence of fatty acid methyl esters, which were confirmed in the GC-FID tests, and the absence of bands between 2500 and $3300 \mathrm{~cm}-1$ indicating low percentage of water in biodiesel studied. Such occurrences allow us to predict the results of some quality control parameters of biodiesel. For example, the values shown in Table $x$ (methyl ester 
composition) for gongo biodiesel lead us to infer as to the degree of FAME saturation that the gongo biodiesel will have:

a) Good ignition quality - the longer the saturated carbonic chain, the higher its cetane number (NC), which provides better combustion conditions,

b) High oxidative stability - the saturated chains make biodiesel more chemically stable, more resistant to oxidation if not stored or transported properly,

c) Low cloud point - saturated chains solidify easily at low temperatures,

d) Good viscosity and low lubricity power - although biodiesel naturally has good lubricity power, methyl esters of unsaturated fatty acids add greater lubricity power relative to biodiesel containing saturated FAME. Conversely, viscosity increases with increasing saturated chains.

e) Moisture content compatible with Resolution 045/2014-ANP - the absence of absorption bands in the infrared region, specifically in the range of 2500 to $3300 \mathrm{~cm}-1$ allows us to predict that gong biodiesel contains low moisture content.

\section{FINAL CONSIDERATIONS}

This work allowed the obtainment of very interesting data about the use of low value-added raw materials aiming at reducing the costs of the process of sustainable biodiesel production. The raw material used was the oil extracted from the larvae of the Pachymerus nucleorum easily found in the native forests of the mesoregion of Alto Turi (Maranhão, Brazil), which has little or almost no commercial value.

The technology for extraction of oil from the larvae of Pachymerus nucleorum is simple and to be suitable for sustainable production of biodiesel should be optimized, since it has a high acidity index, which hinders its direct use in traditional transesterification. On the other hand, the oil yield in the course of thermal extraction is very inviting, and may have a cost-effective effect, which may contribute to biodiesel being more competitive with fossil diesel.

The results revealed throughout the physical-chemical characterization of the oil (in natura and esterified) and of the biodiesel originating from the larvae of Pachymerus 
nucleorum indicated that this oil when previously treated can be used in the transesterification process by basic homogeneous catalysis.

Finally, Brazil in view of its geographical location is a country that emerges with a high potential for the development of innovative technologies in the area of renewable energy production, because it has tropical forests with vast biodiversity consisting of tropical forests rich in mineral resources, with exuberant fauna and flora with food, timber, steel, catalytic, medicinal, and renewable energy applications.

\section{ACKNOWLEDGMENT}

He authors thank the support given by IFMA-Campus Zé Doca, by the Laboratory of Reactivity of Hydrocabinetics, Biomass and Catalysis (Larhco) from UFRJ, by the Research Group in Sustainable Chemical Analysis (GPAQS) from IFMA-Campus Zé Doca. They also thank Luiz Eduardo Santos Vieira for the honorable contribution in the translation of this work written initially in Portuguese and later translated into English. 


\title{
REFERÊNCIAS
}

Agência Nacional de Petróleo, Gás Natural e Biocombustíveis (ANP). Resolução n.45 de 25/08/2014. Disponível em: www.anp.gov.br/biocombustíveis/biodiesel. Acesso em: $15 \operatorname{dez} 2018$.

\begin{abstract}
ALBUQUERQUE, G. A. Obtenção e caracterização físico-química do biodiesel de canola (Brassica napus). 2006, 100f. Dissertação (Mestrado em Química) Universidade Federal da Paraíba, João Pessoa, 2006. Disponível em: http://www.quimica.ufpb.br/ppgq/contents/documentos/teses-edissertacoes/dissertacoes/2006/Dissertacao_Geuza_A_Albuquerque.pdf. Acesso em: 20 nov 2018.
\end{abstract}

ALCHRIS, W. G. A,; SUTANTO, S.; ONG, L. K.; TRAN-NGUYEN, O. L.; ISMADJI, S.; JU, Y. H. Developments in in-situ (trans) esterification for biodiesel production: a critical review. Renewable and Sustainable Energy, v.60, p.284-302, 2016. Disponível em: https://www.sciencedirect.com/science/article/abs/pii/S1364032116001003. Acesso em: 15 dez 2018.

ALEGRIA, A.; ARRIBA, M. J. R.; CUELLAR, J. Biodiesel production using 4dodecylbenzenesulfonic acid as catalyst. Appl. Catal, B.2014, 160, 743. Disponível em: https://www.sciencedirect.com/science/article/abs/pii/S0926337314003725. Acesso em: 22 nov 2018.

ARANSIOLA, E. F., OJUMU, T. V., OYEKOLA. O. O., MADZIMBANUTO, T. J. A review of current technology for biodiesel production: state of the art. Biomass and Bionergy, vol 61, p.276-297, 2014. Disponível em:

https://www.sciencedirect.com/science/article/abs/pii/S0961953413004893. Acesso em: $15 \operatorname{dez} 2018$.

BARBOSA et al. Aproveitamento do óleo das amêndoas de tucumã do amazonas na produção de biodiesel. Acta Amazônica, vol.39, pág. 371-376, 2009. Disponível em: https://www.scielo.br/j/aa/a/8zwx4wqQXgnHN6SWLJTDbbH/?format=pdf\&lang=pt. Acesso em: $18 \mathrm{dez} 2018$.

COSTA, W. C. L et al. Análise físico-química de óleos provenientes de dois municípios da ilha de Marajó-PA. In: $57^{\circ}$ CONGRESSO BRASILEIRO DE QUÍMICA, 10,2017, Gramado(RS). Anais. Gramado, 2017. Disponível em: https://www.abq.org.br/cbq/2017/trabalhos.html. Acesso em: 10 out 2018.

DEY, S.; REANG, N. M. ; P.K. DAS, P. K.; DEB, M. A comprehensive study on prospects of economy, environment, and efficiency of palm oil biodiesel as a renewable fuel. Journal of Cleaner Production, v 286, 2021. Disponível em: https://www.sciencedirect.com/science/article/abs/pii/S0959652620350253. Acesso em: 10 nov 2018.

DRELINKIEWICZ, A. et al. Organosulfonic acid doped polyaniline solid acid catalyst as basic for the formation of esters bio-in reaction of esterification and transesterification. Journal Fuel, v.116, p.760-771, 2014. Disponível em: 
https://www.researchgate.net/publication/273715736_Organo-

sulfonic_acids_doped_polyaniline_-

_Based_solid_acid_catalysts_for_the_formation_of_bio-

esters_in_transesterification_and_esterification_reactions. Acesso em: 15 dez 2018.

ENCINAR, J. M.; SANCHEZ, N. G.; GARCIA, M. L. Study of biodiesel production fron animal fats with free fatty acid content. Bioresource Tecnology, v. 102, p.1090710914. 2011. Disponível em:

https://https://www.sciencedirect.com/science/article/abs/pii/S0960852411013563.

Acesso em: $18 \mathrm{dez} 2018$.

FERREIRA, C. Empoderamento: Quem já comeu gongo de babaçu?. Disponível em: http://saomateusdomaranhao.blogspot.com/2010/10/quem-ja-comeu-gongo-de-cocobabacu.html. acesso em 25 fev 2018.

INSTITUTO ADOLFO LUTZ. Normas analíticas do Instituto Adolfo Lutz, v.1: Método químico e físicos para análise de alimentos- óleos e gorduras. 5 ed. São Paulo. IMESP, 2004.

INSTITUTO ADOLFO LUTZ. Normas analíticas do Instituto Adolfo Lutz, v.1: Método químico e físicos para análise de alimentos- óleos e gorduras. 5 ed. São Paulo. IMESP, 2004.

MELERO, J. A.; IGLESIAS, J; MORALES, G. Heterogeneous acid catalysts for biodiesel produce: current status and future challenges. Green chemistry. V11, n.9, p.1285-1308,2009. Disponível em:

https://pubs.rsc.org/en/content/articlelanding/2009/gc/b902086a/unauth. Acesso em 15 set 2018 .

MORETO, E.; ALVES, R. F. Óleos e gorduras: processamento e análise.

Florianópolis: Ed. Da UFSC,1986.

MORETO, E.; FETT, R. Introdução à ciência de alimentos. Florianópolis (SC). Ed. da UFSC, 144p, 2002.

MURTA, A. L. S.; DE FREITAS, M. A. V.; FERREIRA, C. G.; PEIXOTO, M. M. C. L. The use of palm oil biodiesel blends in locomotives: An economic, social and environmental analysis. Renewable Energy, v.164, p. 521-530, 2021. Disponível em: https://www.sciencedirect.com/science/article/abs/pii/S0960148120313392. Acesso em: 10 out 2018 .

NATJA-NAN, B. N.; KIATKITTIPONG, W.; AIOUACHE, F.; ASSABUMRUNGRAT, S. Process design of continuous biodiesel production by reactive distillation: comparison between homogeneous and heterogeneous catalysts. Chemical Engineering and Processing : Process Intensification, v.92, p.33-34, 2015. Disponível em:

https://www.sciencedirect.com/science/article/abs/pii/S0255270115000823. Acesso em: 12 set 2018 .

OLIVEIRA, M. E. C. Produção de biodiesel de óleo de palma e seus resíduos graxos por transesterificação e esterificação. Embrapa Documentos 339. Brasília: 2008.

Disponível em: 
https://www.infoteca.cnptia.embrapa.br/bitstream/doc/410145/1/Doc339.pdf. Acesso em: 18 nov 2018.

POURHOSEINI A, S. H.; NAMVAR-MAHBOUB, E. M.; HOSSEINI, B. E.; ALIMORAD, C. A. A comparative exploration of thermal, radiative and pollutant emission characteristics of oil burner flame using palm oil biodiesel-diesel blend fuel and diesel fuel. Energy, v.217, 2021. Disponível em:

https://www.sciencedirect.com/science/article/abs/pii/S0360544220324452. Acesso em: $22 \operatorname{dez} 2018$.

POUSA, G.P.A.G., SANTOS, A.L.F., SUAREZ, P.A.Z. History and Policy of biodiesel in Brazil. Energy Policy, 35, 5393-5398, 2007. Disponível em: https://www.sciencedirect.com/science/article/abs/pii/S030142150700211X. Acesso em: 15 set 2018 .

RAMPAZZO, V. Avaliação térmica de óleos vegetais por termogravimetria, cromatografia gasosa e espectroscopia de infravermelho médio. 2015, $93 \mathrm{f}$.

Dissertação (Mestrado em Engenharia de Alimentos) - Universidade Federal do Paraná, Curitiba, 2015. Disponível em: https://www.acervodigital.ufpr.br/handle/1884/40603. Acesso em: 10 nov 2018.

SILVA, T. A. R. Biodiesel de óleo residual: produção através da transesterificação por metanólise e etanólise básica, caracterização físico-química e otimização das condições reacionais. 2011, 151f. Tese (Doutorado em Química) - Universidade Federal de Uberlândia, Uberlândia, 2011. Disponível em: http://clyde.dr.ufu.br/handle/123456789/17506. Acesso em: 15 set 2018.

SOUZA, B. R.; SOUSA. T. L.; ALVES, W. S.; VIEIRA, J. S. C. Resumos do $5^{\circ}$ Congresso da Rede Brasileira de Tecnologia de Biodiesel, Salvador, Brasil, 2012. Disponível em:

https://www.scielo.br/j/qn/a/stcV69RwbDBMnRCpYShkJny/?lang=pt\&format=pdf. Acesso em: 12 nov 2018.

SUAREZ, P. A. Z.; MENEGHETTI, S. M. P.; MENEGHETTI, M. R.; WOLF, C. R. Quim. Nova. 2007, 30, 667. Disponível em:

https://www.scielo.br/j/qn/a/wp6nqZqXMpXHsfKdrMh69zm/?lang=pt. Acesso em: 13 nov 2018.

TECNOLOGIAS BIOENERGÉTICAS. Procedimentos operacional padrão da Brasil Ecodiesel- Análise do controle de Qualidade, 30p, 2008.

VIEIRA et al. Esterificação e transesterificação homogênea de óleos vegetais contendo alto teor de ácidos graxos livres. Quim. Nova, vol. 1, nº 1, p10-16, 2018. Disponível em:

https://www.scielo.br/j/qn/a/stcV69RwbDBMnRCpYShkJny/?lang=pt\&format=pdf. Acesso em: 20 set 2018.

VIEIRA, J. S. C. Síntese de catalisadores heterogêneos ácidos e básicos para a produção de biodiesel. 2017, 144f. Tese (Doutorado em Engenharia de Processos Químicos e Bioquímicos) - Escola de Química. Universidade Federal do Rio de Janeiro, 
Rio de Janeiro, 2017. Disponível em: http://186.202.79.107/download/sintese-decatalisadores-heterogeneos-acidos-e-basicos-para-producao-de-biodiesel.pdf. Acesso em: 10 out 2018 .

ZUO, D. et al. Sulfonic acid functionalized mesoporus SBA-15 catalysts for biodiesel production. Applied Catalysis B: Environmental, V.129, p.342-350, 2013. Disponível em: https://www.sciencedirect.com/science/article/abs/pii/S092633731200. Acesso em: 12 dez 2018.

Recebido em: 01/09/2021

Aprovado em: 20/09/2021

Publicado em: 27/09/2021 